\title{
Characterization and Identification of Native Plant Growth-Promoting Bacteria Colonizing Tef (Eragrostis Tef) Rhizosphere During the Flowering Stage for A Production of Bio Inoculants
}

\author{
Zerihun Tsegaye*, Mohammed Yimam, Dagne Bekele, Solomon Chaniyalew and Fasil Assefa \\ Department of Microbial, College of Natural Science, Cellular and Molecular biology, Debreziet agricultural researchcenter, Ethiopia
}

*Corresponding author: Zerihun Tsegaye, College of Natural Science, Department of Microbial, Cellular and Molecular biology,

Ministry of innovation and technology, Ethiopian Biodiversity Institute. Debreziet agricultural research center, Ethiopia

\begin{abstract}
ARTICLE INFO
Received: 慧 October 10, 2019

Published: 慧 October 18, 2019

Citation: Zerihun Tsegaye, Mohammed Yimam, Dagne Bekele, Solomon Chaniyalew, Fasil Assefa. Characterization and Identification of Native Plant Growth-Promoting Bacteria Colonizing Tef (Eragrostis Tef) Rhizosphere During the Flowering Stage for A Production of Bio Inoculants. Biomed J Sci \& Tech Res 22(2)-2019. BJSTR. MS.ID.003710.
\end{abstract}

Keywords: Rhizobacteria; Nitrogen Fixation; Phosphate Solubilization; Growth Promotion

\section{ABSTRACT}

The Plant Growth-Promoting Rhizobacteria (PGPR) are the free-living plant roots colonizing bacteria that improve soil fertility, stimulating plant growth, and protecting plants from biotic and abiotic stress factors. The present study was conducted to characterize and identify native PGP bacteria colonizing tef rhizosphere during the flowering stage for a production of bio inoculant. For this concern, 426 samples of different varieties of tef roots and rhizosphere soils were collected. A total of 457 rhizobacteria were isolated and characterized for PGP traits, biocontrol properties, and abiotic stress tolerance ability. 12 rhizobacterial species were identified using the Biolog bacterial identification system. Among these, the majority of the identified bacterial species were utilized different carbon sources that similar to plant root exudates i.e. carbohydrates, carboxylic acids, amide, and amine.

Seed germination and seedling growth test were conducted using four identified bacterial species having excellent plant growth-promoting, biotic and abiotic stress tolerance properties, and 100 percent tef seeds germination result occurred on $3^{\text {rd }}$ and $4^{\text {th }}$ day after inoculation. shoot and root length of inoculated seeds was measured on last day of the experiment to determine the effect of PGP bacteria on tef crops growth enhancement and increase mean shoots and root length up to 3 and $2.6 \mathrm{~cm}$ respectively in comparison to control. PGP bacterial species or strains can be used as bio inoculants to replacing chemical fertilizers for sustaining agricultural productivity and production without affecting soil fertility, living organisms, and their environment.

\section{Introduction}

The rhizosphere is the region of soil that is affected by root secretions and soil associated microorganisms [1]. It is a nutrientrich region as compared to the bulk soil due to the accumulation of root exudates carrying a large number of carbohydrates and amino acids, serve as a rich source of energy and nutrients for rhizosphere microbes. Rhizosphere has been broadly classified into the three major zones.

1) Endorhizosphere: that consists of the root tissue including the endodermis and cortical layers;
2) Rhizoplane: where soil particles and microbes adhere. It consists of epidermis, cortex and mucilaginous polysaccharide layer;

3) Ectorhizosphere: that consists of soil closely adjacent to the root [2].

The rhizosphere is enriched with a variety of microorganisms and the bacteria residing in this region are called rhizobacteria [2]. Rhizobacteria are bacteria that inhabiting plant roots; they can multiply and colonize all the ecological niches found on the roots at all stages of plant growth, in the presence of a competing 
microflora in the rhizosphere [3]. Rhizobacteria can have a neutral, harmful or beneficial effect on plant growth, yield, and grain quality. Harmful rhizobacteria are presumed to badly affect plant growth and development through the production of undesirable metabolic products. Beneficial rhizobacteria are termed as PGPR according to their mode of action. They are a group of free-living saprophytic bacteria that can be found in the rhizosphere in association with the root system and enhance plant growth and yield. It provides high adaptability in a wide variety of environments, faster growth rate, and a biochemical versatility that allows them to metabolize a wide range of natural and xenobiotic compounds. PGPR is characterized by the following properties

(i) They must be able to colonize the root surface

(ii) They must survive and multiply in rhizosphere associated with the root surface, in competition with other microorganisms and

(iii) They must promote plant growth and control plants from phytopathogens [5].

PGPR directly affect plant growth by improving nutrient assimilation through fixation of atmospheric nitrogen, solubilization of phosphorus, siderophores production and/or other unavailable forms of nutrients. Production and/or suppression of growthregulating hormones (auxins, gibberellins, and cytokines) are another effective direct mechanism for plant growth enhancement [6]. Indirect mechanisms include competition for niche, production of antibiotic, production of lytic enzymes, ammonia production, HCN production, exopolysaccharide production and increased disease resistance ability of the plants [7]. It improves physicochemical and biological properties of the degraded substrates and makes them more suitable for plants with simultaneous increase of plant survival and seedling quality. Positive outcomes of PGPR application are an enhancement of seedlings emergence, faster plant growth, higher biomass production, an increase of root length, and branching, increased leaf area, and chlorophyll content [8].

PGPR species or strains also possess the enzyme ACC deaminase [9] and this enzyme can cleave the plant ethylene precursor ACC to ammonia and a-ketobutyrate thereby lowers the level of ethylene under various biotic and abiotic stress factors [10] such as salt stress, flooding stress, drought stress, heavy metal stress, and pathogen attack. Soil-borne pseudomonads fluorescent have excellent root colonizing capacity, catabolic versatility and produce a wide range of enzymes and metabolites that favor the plant withstand under varied biotic and abiotic stress conditions [11]. The improvement of plant growth can vary depending on colonization areas of PGPR on the host plant. It may inhibit the rhizosphere, the surface of the root, or even superficial intercellular spaces of the host plant [12]. The process of bacterial root colonization is under the influence of several mechanisms such as bacterial traits, root exudates production and several other biotic and abiotic stress factors [13]. Some authors reported that bacterial cells first inhabit the rhizosphere following inoculation into the soil [14]. Then, bacterial cells may occur as single cells attached to the root surfaces and consequently converted into doublets on the rhizodermis, forming a string of bacterial cells [15].

Bacterial colonization may then occur on the whole surface of plants and can even establish as micro-colonies (bio-films). It is important to note that the root system is not inhabited uniformly, different population densities being reported for the diverse root zones. For example, Kluyvera ascorbate inhabited the upper twothirds of the surface of canola roots, but no bacteria were detected around plant root tips [16]. Non-uniform bacterial colonization along the plant root can be explained by different factors such as varying root exudation patterns, bacterial quorum sensing effects as well as many other factors. The aim of this study is an isolate, characterize and identify potential PGP bacterial species or strains for production of bio inoculums serve as Biofertilizer and biocontrol to improve tef crops production and productivity without affecting soil fertility, living organisms, and their environment.

\section{Material and Methods}

\section{Study Area}

This study was conducted in East Shewa Zone, Oromia Regional State, Ethiopia from 2009 to 2011 E.C. According to zonal statistics and information center, the zone is found between $38^{\circ} 57^{\prime}$ and $39^{\circ} 32^{\prime} \mathrm{E}$ and $7^{\circ} 12^{\prime}$ and $9^{\circ} 14^{\prime} \mathrm{N}$ and classified into three traditional agro-climatic zones [17]. The average altitude of the zone is 1,600 $\mathrm{m}$ but rises to 2,420 $\mathrm{m}$ at the northwestern and it falls to $900-1000$ $\mathrm{m}$ towards the northeast [18] (Figure 1).

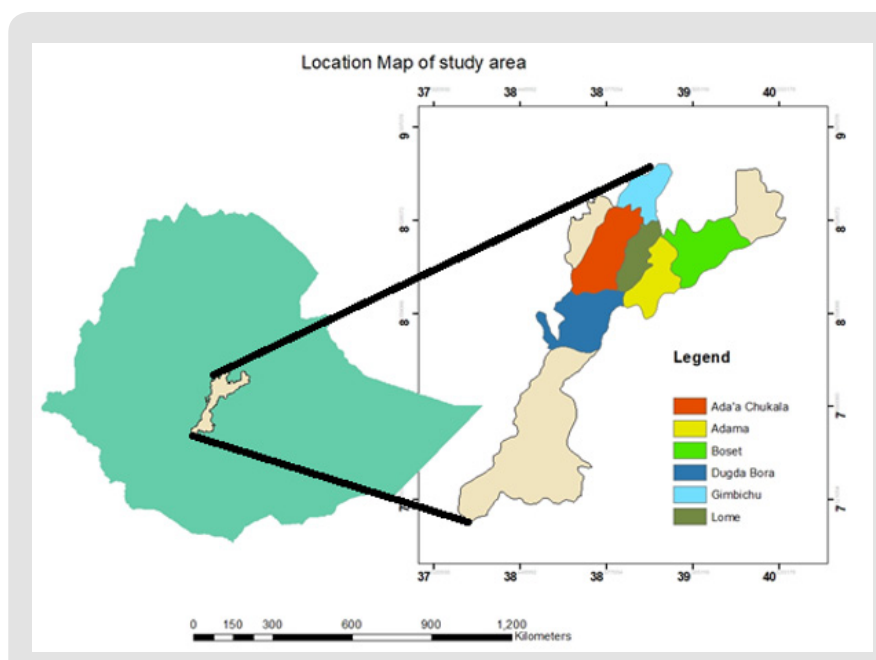

Figure 1: Map of study area.

\section{Soil Sample Collection and Analysis}

71 composites soil samples were collected from the rhizosphere of cultivated tef varieties at a depth $0-20 \mathrm{~cm}$ using an auger and these soil samples were dried, sieved through $2 \mathrm{~mm}$ sieve to have $1 \mathrm{~kg}$. The collected soil samples were then analyzed for selected physical and chemical properties like soil texture, pH, Electric Conductivity (EC), Organic Matter (OM), available phosphorus [19] and total nitrogen 
[20] at Debrezeit agricultural research center. A total of 426 (213 rhizosphere soil and 213 roots) samples were collected from the rhizosphere of cultivated tef varieties for microbial isolation.

\section{Bacterial Isolation}

For isolation of rhizosphere bacteria, 10gram of the soil was mixed in $90 \mathrm{ml}$ of saline solution $(0.9 \% \mathrm{NaCl})(\mathrm{w} / \mathrm{v})$ to make a suspension. The prepared suspension was shacked for 5 minutes to remove unwanted substance such as soil, debris and dead bacterial cells from the samples. For isolation of root adhering bacteria, fresh roots were washed with distilled water to make a solution. Soil suspension and root washing solutions were serially diluted (from 10-1 to 10-6) respectively. $0.1 \mathrm{~mL}$ of supernatant from each dilution of rhizosphere soil and root washing solution was transferred onto prepared solid medium and incubated at the appropriate temperature. All the bacterial isolates were morphologically characterized as per the method described in Berge's manual of determinative bacteriology and in vitro evaluated for different bacterial plant growth-promoting traits, biocontrol properties, and abiotic stress factors tolerance activities.

\section{Characterization of Bacterial Isolates for their Plant Growth-Promoting Traits}

All the isolates were characterized for bacterial PGP traits such as nitrogen fixation, phosphate solubilization, organic acid production, Indole Acetic Acid (IAA) production.

Test For Nitrogen Fixation: To characterize the isolates' ability to fix atmospheric nitrogen, qualitative screening of growth was done on solid $\mathrm{N}$-free medium $\left(1 \mathrm{~g} \mathrm{~K}_{2} \mathrm{HPO}_{4}, 5 \mathrm{mg} \mathrm{FeSO} \cdot 7 \mathrm{H}_{2} \mathrm{O}, 1\right.$ $\mathrm{g} \mathrm{CaCO}_{3}, 0.2 \mathrm{~g} \mathrm{NaCl}, 0.2 \mathrm{~g} \mathrm{MgSO}_{4} \cdot 7 \mathrm{H}_{2} \mathrm{O}, 5 \mathrm{mg} \mathrm{NaMoO}$, 10 g glucose per liter, and $1.5 \%$ agar at pH 7.0). Visible bacterial colonies on the $\mathrm{N}$-free medium were used as the growth parameter [21].

Test for Phosphate Solubilization Activity: Bacterial isolates were spot inoculated on the Pikovskay's agar medium plates and incubated at $30^{\circ} \mathrm{C}$ for 5 days. The appearance of the clear zone around bacterial growth was used as an indicator for positive bacterial phosphate solubilization activities [22].

Test for Organic Acid Production: The bacterial organic acid production test was conducted by inoculating test bacterial culture in minimal salt medium broth for 2 to 3 days at $30^{\circ} \mathrm{C}$. The appearance of pink color in the medium indicates a positive result for bacterial organic acid production using methyl red as an indicator [23].

Production of Indole Acetic Acid (IAA): IAA production was detected as described by [24]. Bacterial cultures were grown on Luria Bertani (LB) broth amended with $100 \mathrm{mg} / \mathrm{l}$ tryptophan as the precursor of IAA and incubated in a shaker at $250 \mathrm{rpm}$ at $30^{\circ} \mathrm{C}$ for 3 to 5 days. Fully grown cultures were centrifuged at 10,000 rpm for $10 \mathrm{~min} .2 \mathrm{ml}$ of the supernatant was mixed with $4 \mathrm{ml}$ of the salkowski reagent ( $50 \mathrm{ml}, 35 \%$ of $\mathrm{HClo}_{4}, 1 \mathrm{ml} 0.5 \mathrm{~m} \mathrm{FeCl}_{3}$ solution). Formation of pink color in test tubes was indicating a positive result for bacterial IAA production.

\section{Characterization of Bacterial Isolates for their Biocontrol Properties}

All the rhizobacterial isolates were characterized for phytopathogens controlling properties such as ammonia production, hydrogen cyanide production, hydrolytic enzymes production, and exopolysaccharide production.

Production of ammonia. Bacterial isolates were tested to produce ammonia in peptone water described by Kumar et al. [25]. Freshly grown rhizobacterial isolates were inoculated in the tubes containing $10 \mathrm{ml}$ peptone water and incubated for $48 \mathrm{~h}$ at $30^{\circ} \mathrm{C}$. Nessler's reagent $(0.5 \mathrm{ml})$ was added in each tube. Formation of brown to yellow color indicates a positive result for bacterial ammonia production.

\section{Hydrogen Cyanide (HCN) Production Test}

Bacterial isolates were tested for HCN production by the methodology described by Castric [26]. The isolates were transferred on the nutrient media plates containing 4.4 g glycine per liter. To the top of the plate, Whatman filter paper no. 1 soaked in $2 \%$ sodium carbonate in $0.5 \%$ picric acid solution was placed and sealed with parafilm. The plates were incubated at $30^{\circ} \mathrm{C}$ for 4 days and observed for a color change of the filter paper from deep yellow to reddish-brown indicated positive result for bacterial HCN production.

\section{Hydrolytic Enzyme Production Test}

Rhizobacterial isolates were tested for their hydrolytic enzyme production like protease, cellulase, amylase, and pectinase.

\section{Protease Production Test}

Bacterial isolates were tested for their ability to produce proteolytic enzymes onto skim milk agar $3 \% \mathrm{v} / \mathrm{v}$ ) medium $[27,28]$. The diameter of the clear zone formed around the growing bacterial colonies was measured after $48 \mathrm{~h}$ of incubation at $30^{\circ} \mathrm{C}$. Bacterial isolates showing clear zone on the proteolytic medium was indicated a positive result for protease production.

\section{Cellulase Production Test}

Pure cultures of bacterial isolates were individually transferred onto CMC agar plates. After incubation for 48 hours, CMC agar plates were flooded with $1 \%$ Congo red and allowed to stand for $15 \mathrm{~min}$ at room temperature. One molar $\mathrm{NaCl}$ was thoroughly used for counterstaining the plates. Clear zones were appeared around growing bacterial colonies after 48 hours of incubation at $30^{\circ} \mathrm{C}$ indicating bacterial cellulose production [29].

\section{Amylase Production Test}

The bacterial isolates were spot inoculated on starch agar medium plates and incubated at $30^{\circ} \mathrm{C}$ for $48 \mathrm{~h}$. At the end of the incubation period, the plates were flooded with iodine solution, kept for a minute and then poured off. Iodine reacts with starch to form a blue color compound. This blue color fades rapidly. 
Hence the colorless zone surrounding bacterial colonies indicates bacterial ability to produce amylase [30].

\section{Pectinase Production Test}

The rhizobacterial isolates were spot inoculated on the pectin agar plates and incubated for one week at $30^{\circ} \mathrm{C}$. The plates then were flooded with $1 \%$ iodine solution for one hour, drained, rinsed with water and observed halo zone formation around growth colonies indicating bacterial pectinase production [31].

\section{Exopolysaccharide (EPS) Production}

Rhizobacterial isolates were tested for EPS production ability using solid medium such as Burk's medium (g/1: Sucrose, 20.0; $\mathrm{K}_{2} \mathrm{HPO}_{4}, 0.80 ; \mathrm{KH}_{2} \mathrm{PO}_{4^{\prime}}, 0.20 ; \mathrm{MgSO}_{4} .7 \mathrm{H}_{2} 0,0.20 ; \mathrm{NaCl}, 0.20 ; \mathrm{CaSO}_{4^{\prime}}$ $0.10,0.1 \mathrm{ml}$ of Fe-Mo Mixture $\left(\mathrm{FeCl}_{3} \cdot 6 \mathrm{H}_{2} \mathrm{O} 1.45 \mathrm{~g}\right.$ and $\mathrm{Na}_{2} \mathrm{MoO}_{4}$ $2 \mathrm{H}_{2} \mathrm{O}, 0.253 \mathrm{~g}$ in $100 \mathrm{ml}$ ), $\mathrm{H}_{3} \mathrm{BO}_{3}, 10 \mu \mathrm{g} ; \mathrm{ZnSO}_{4}, 10 \mu \mathrm{g}$; $\mathrm{MnSO}_{4}, 1 \mu \mathrm{g}$; CUSO $_{4} .5 \mathrm{H}_{2} \mathrm{O}, 0.3 \mu \mathrm{g}$; KI, $0.1 \mu \mathrm{g}$ and Agar 25.0) and observed for mucoid colony formation on Burk's medium. And also rhizobacterial isolates were extracted and confirmed for exopolysaccharide production using cold acetone through observation of precipitate formation [32].

\section{Characterization of Bacterial Isolates for Abiotic Stress Tolerance Ability}

Stress tolerance test was carried out by growing the bacterial isolates at different abiotic stress factors such as temperature, $\mathrm{pH}$, and salinity. Temperature is one of the abiotic stress factors that affect plant growth and yield. Temperature effects on PGP bacterial isolates were studied by streaking the isolates on nutrient agar plates and incubating at $4,20,30,40,50$ and $60^{\circ} \mathrm{C}$ for $48 \mathrm{~h}$ and observed for colonial growth on agar medium. $\mathrm{pH}$ is another stress factor that affects plant growth, for this rhizobacterial isolates were transferred on to nutrient agar with $\mathrm{pH} 4,5,7,9,11$ and 13 was prepared using $\mathrm{H} 2 \mathrm{SO} 4$ and $\mathrm{KOH}$. Bacterial isolates were streaked on a different medium and grown at $30^{\circ} \mathrm{C}$. Likewise, for salinity stress nutrient agar medium with $0.86,1.7,2.3$ and $3.4 \mathrm{M} \mathrm{NaCl}$ (5\%, 10\%, $15 \%$ and $20 \% \mathrm{NaCl}$ ) was prepared and the isolates were grown on the medium at $30^{\circ} \mathrm{C}$ and observe their growth on agar medium.

\section{Biochemical Characterization and Identification of PGP Bacteria}

Biochemical bacterial characterizations were carried out using the procedures described in the Bergey's Manual of Systematic Bacteriology. Morphological identification of PGPR isolates was performed using morphological characterization. After $24 \mathrm{~h}$ of bacterial isolates growth on peptone agar at $30^{\circ} \mathrm{C}$ and characterized for their following traits i.e. color, shape, size, surface, opacity, and texture. Cellular morphology such as color and shape and also division mode was identified by using light microscopy. Carbon source utilization patterns of rhizobacterial isolates having plant growth-promoting traits, biocontrol and stress tolerance properties were analyzed using Biolog OmniLog ${ }^{\circledR}$ ID System which is now widely available to assess functional diversity of bacteria and fungi in the rhizosphere. Biolog is patented technology and automated/ semi-automated biochemical and physiological tests that analyze microbial ability to utilize particular carbon sources, and chemical sensitivity assays.

The Biolog OmniLog identification system is that characterizes the ability of microorganisms to utilize or oxidize (simply "Biolog" Inc, Hayward, California), a system that used Gene III microplate containing 94 phenotypic panels of 71 carbon sources assays and 23 chemical sensitivity assays including $\mathrm{pH}$ and salt. The test panel provides a "Phenotypic fingerprint" of the microorganism that can be used to identify it at the species and strain level. The plates contained 96 wells, with a dehydrated panel of necessary nutrient medium and tetrazolium violet. Tetrazolium violet is incorporated in each of the substrates contained in a well of the microplate. As a bacterium begins to use the carbon sources in certain wells of the microplate, it respires. With bacteria, this respiration process reduces a tetrazolium redox dye and those wells change color to purple. The result is a pattern of colored wells on the microplate that is characteristic of that bacterial species. PGP bacterial isolates were prepared according to the manufacturer's instructions in the OmniLog ID System user guide (Biolog, Hayward, CA). All isolates were transferred on a Biolog universal growth (BUG) agar and incubated at $30^{\circ} \mathrm{C}$ for 24 hours. After an incubation period, pure colonies were picked with a sterile wooden Biolog Streakerz ${ }^{\mathrm{TM}}$ stick and rubbed around the walls of a test tube containing inoculating fluid (A) protocol and measure optical density (from 90 to 98) of the inoculum using Biolog turbidimeter. $100 \mu \mathrm{L}$ of the bacterial suspension was transferred into each well of GenIII microplates using multi-channel pipettor and incubated at $30^{\circ} \mathrm{C}$.

Read the microplate using Biolog's microbial identification systems software (OmniLog ${ }^{\circledR}$ Data Collection) after the period of 18 , 24 and 48 hours incubation. Each metabolic profile of inoculated PGPR was compared with the Omnilog Biolog database (Biolog, Hayward, CA) and identified at the species level.

\section{Seed Germination and Seedling Growth Test}

Seed germination tests were carried out to determine the effect of inoculated rhizobacterial species or strains on the rates of seed germination and seedling growth [32]. For this, tef seeds were used as plant materials. Healthy seeds were surface sterilized with $70 \%$ alcohol for $3 \mathrm{~min}$ and followed with 1\% hypochlorite for 5 minutes and rinsed 5 times with sterile distilled water. Four PGPR species or strains (single and consortium) were grown in nutrient broth on shaking incubator $(180 \mathrm{rpm})$ at $30^{\circ} \mathrm{C}$ for $24 \mathrm{~h}$. The surface-sterilized seeds of tef were inoculated in broth culture of the PGPR species or strain cultures for 30 min including normal water (C) as control. 25 inoculated seeds of each treatment were placed in separate Petriplate containing soaked filter papers and the Petri-plates were incubated at room temperature for 7 days. Seed germination was recorded regularly starting from the 2 nd day based on the number of the germinated seed out of total germination. 
Each treatment was replicated three times. Percentages of germination and seedling growth were calculated and evaluated the effect of single and consortium-seed bacterization on a shoot and root growth of tef crops. Vigor index of seedling was measured on the last day of the experiment according to the formula proposed by Abul-Baki \& Anderson [33]. Seed vigor index = (mean shoot length + mean root length) $\times$ germination $\%$.

\section{Methods of Data Analysis}

Data analysis was carried out using the chart, table, frequency, and percentiles using excel to evaluate PGP traits, biocontrol properties, and abiotic stress tolerance of native plant growthpromoting rhizobacteria.

\section{Results}

\section{Soil Physiochemical Analysis}

71 composites soil samples were collected from a depth of $0-20 \mathrm{~cm}$ using auger and these soil samples were dried, sieved through $2 \mathrm{~mm}$ sieve to have $1 \mathrm{~kg}$. The collected soil samples were then analyzed for selected physical and chemical properties mainly soil texture, $\mathrm{pH}$, organic matter, organic carbon, total nitrogen, available phosphate, and electrical conductivity. The majority of the soil samples collected from the study area was found to be in the alkaline $\mathrm{pH}$ range [34]. $73.4 \%$ of soil samples were found to be in the lower range of total nitrogen, $26.6 \%$ soil samples were found to be in the medium range of total nitrogen. $66.7 \%$ of soil samples were found to be in the lower range of available phosphate and $26.3 \%$ of were found to be in the medium range of available phosphate and $7 \%$ were found to be in the higher range of available phosphate. For availability of the organic matter, $90.7 \%$ of soil sample was found to be in the lower range and $9.3 \%$ were found to be in the medium range of organic matter.

For electrical conductivity were the majority of the experimental soil samples its electrical conductivity was found to be at the acceptable range for crop production (Table 1).

Table 1: Results of the soil physiochemical analysis for different soil properties.

\begin{tabular}{|c|c|c|c|c|c|c|c|}
\hline Districts & Soil types & pH & E.C & TN & AV.P & $\% 0 M$ & $\% 0 \mathrm{C}$ \\
\hline \multirow{5}{*}{ Boset } & Clay & $7.20-7.30$ & 0.04-0.05 & 0.04-0.05 & $5.00-5.12$ & $2.00-2.30$ & $1.16-1.33$ \\
\hline & Loam & $7.92-8.15$ & $0.10-0.11$ & $0.11-0.15$ & $6.15-7.52$ & $1.28-2.72$ & $0.74-1.58$ \\
\hline & Clay loam & $7.40-7.97$ & $0.03-0.13$ & $0.12-0.15$ & $6.10-9.76$ & $0.79-2.29$ & $0.46-1.33$ \\
\hline & Silt loam & 7.80-8.02 & $0.13-0.15$ & $0.11-0.14$ & 28.06-28.17 & $0.85-0.97$ & $0.49-0.56$ \\
\hline & Sandy loam & 7.33-7.95 & $0.03-0.11$ & $0.10-0.13$ & $8.47-9.37$ & $0.80-3.073$ & $0.47-2.17$ \\
\hline \multirow{4}{*}{ Lume } & Clay & $7.80-7.85$ & $0.07-0.08$ & $0.09-0.11$ & $2.29-4.94$ & $1.04-1.06$ & $0.60-0.62$ \\
\hline & Loam & 7.16-8.55 & $0.04-0.10$ & $0.07-0.20$ & $1.53-16.17$ & $1.22-1.90$ & $0.71-1.10$ \\
\hline & Clay loam & $7.60-7.77$ & $0.05-0.06$ & $0.09-0.10$ & $4.30-4.35$ & $1.62-1.72$ & $0.94-1.00$ \\
\hline & Sandy loam & $7.27-7.91$ & $0.03-0.05$ & $0.09-0.11$ & $3.06-4.12$ & $1.22-1.29$ & $0.71-0.75$ \\
\hline \multirow{3}{*}{ Ada'a } & Clay & $6.83-7.38$ & 0.04-0.09 & 0.08-0.15 & $1.66-10.19$ & $0.85-3.15$ & $0.49-1.83$ \\
\hline & Loam & $6.93-6.95$ & $0.07-0.08$ & 0.14-0.15 & $26.60-33.17$ & $1.14-1.15$ & $0.66-0.67$ \\
\hline & Clay loam & $6.83-7.83$ & $0.05-0.06$ & $0.11-0.17$ & $12.54-55.40$ & $1.11-1.17$ & $0.65-0.68$ \\
\hline \multirow{3}{*}{ Adama } & Loam & 7.86-8.30 & $0.05-0.12$ & $0.11-0.13$ & $4.98-9.82$ & $0.95-1.17$ & $0.55-0.68$ \\
\hline & Sandy loam & 7.88-8.49 & $0.07-0.13$ & $0.08-0.14$ & $6.12-18.39$ & $0.85-3.15$ & $0.49-1.83$ \\
\hline & Silt loam & 7.48-7.50 & $0.10-0.11$ & $0.13-0.16$ & $6.11-6.24$ & $0.90-0.94$ & $0.52-0.55$ \\
\hline \multirow{2}{*}{ Dugdabora } & Clay loam & $7.63-8.92$ & $0.02-0.06$ & $0.16-0.17$ & $12.17-17.64$ & 0.94-0.95 & $0.54-0.55$ \\
\hline & Sandy loam & $8.40-8.60$ & $0.07-0.08$ & $0.10-0.12$ & $8.90-8.94$ & $1.15-1.17$ & $0.67-0.68$ \\
\hline Gimbichu & Clay & $6.82-7.77$ & $0.03-0.06$ & $0.09-0.14$ & $11.35-16.58$ & $0.79-1.41$ & $0.46-0.82$ \\
\hline
\end{tabular}

\section{Bacterial Isolation}

For the preliminary morphological characterizations of potential PGPB, 457 pure bacterial colonies colonizing tef rhizosphere during the flowering stage were isolated and characterized for their colonial morphology traits i.e. size, shape, color, margin, elevation, and opacity and their cellular morphology such as color and shape using light microscopy. The highest percentage occurrence of the tef rhizosphere bacterial isolates on culture media belongs to phylum of Proteobacteria and class gammaproteobacteria.

\section{Characterization of Bacterial Isolates for Plant Growth- Promoting Traits}

457 pure bacterial isolates associated with tef rhizosphere were characterized for different PGP traits such as phosphate solubilization, organic acid production, IAA production, growth on 
nitrogen-free medium and NH3 production. Among these, 71.3\% (326) rhizobacterial isolates were positive for phosphate solubilization test, $57.1 \%$ (261) isolates were positive for IAA production,
$52 \%$ (238) isolates were positive for organic acid production and $12 \%$ (55) positive for ammonia production and $10 \%$ (46) bacterial isolates were grown on nitrogen-free medium (Table 2).

Table 2: Characterization of bacterial isolates for plant growth-promoting traits.

\begin{tabular}{|c|c|c|c|c|c|c|c|}
\hline \multirow{2}{*}{ S.No } & \multirow{2}{*}{$\begin{array}{c}\text { Code of bacterial } \\
\text { isolates }\end{array}$} & \multicolumn{2}{|c|}{ Phosphate solubilization } & \multirow{2}{*}{$\begin{array}{l}\text { Organic acid } \\
\text { production }\end{array}$} & \multirow{2}{*}{ IAA production } & \multirow{2}{*}{$\begin{array}{l}\text { Nitrogen } \\
\text { fixation }\end{array}$} & \multirow{2}{*}{$\begin{array}{l}\text { Ammonia } \\
\text { production }\end{array}$} \\
\hline & & Clearance & SI & & & & \\
\hline 1 & $2^{\text {nd }}$ f soil- 1 & +++ & 2.5 & ++ & +++ & - & - \\
\hline 2 & $2^{\text {nd }}$ f soil- 5 & ++ & 2.2 & ++ & +++ & - & - \\
\hline 3 & $2^{\text {nd }}$ f soil- 20 & ++++ & 3.2 & +++ & + & - & - \\
\hline 4 & $2^{\text {nd }}$ f soil- 30 & ++++ & 4 & ++ & ++ & +++ & +++ \\
\hline 5 & $2^{\text {nd }} f$ RW-8st & ++ & 2.3 & + & +++ & + & +++ \\
\hline 6 & $2^{\text {nd }} f R W-10$ & + & 2 & + & +++ & - & - \\
\hline 7 & $2^{\text {nd }} f \mathrm{RW}-11$ & ++ & 2.3 & + & +++ & - & - \\
\hline 8 & $2^{\text {nd }} f \mathrm{RW}-15$ & +++ & 2.6 & + & +++ & - & - \\
\hline 9 & $2^{\text {nd }} f$ RW-27 & ++ & 2.5 & + & ++ & + & +++ \\
\hline 10 & $2^{\text {nd }} f \mathrm{RW}-29$ & ++ & 2.4 & - & + & - & - \\
\hline 11 & $2^{\text {nd }} f$ RW-38 & ++ & 2.1 & - & +++ & - & - \\
\hline 12 & $2^{\text {nd }} f \mathrm{RW}-42 \mathrm{nd}$ & ++ & 2 & - & +++ & - & - \\
\hline
\end{tabular}

Characterization of Bacterial Isolates for Bacterial Biocontrol Properties

457 bacterial isolates were screened for bacterial biocontrol properties such as lytic enzyme production, HCN production, and EPS production. The percentage occurrences of the isolates, $65.4 \%$
(299) isolates were positive for protease production, $20.6 \%$ (95) were positive for amylase production, $8 \%$ (37) were positive for cellulase production and $0.3 \%$ (2) were positive for pectinase production, $18.6 \%$ (85) bacterial isolates were positive for EPS production, $15.4 \%$ (70) were positive for HCN production (Table 3).

Table 3: Characterization of bacterial isolates for bacterial biocontrol properties.

\begin{tabular}{|c|c|c|c|c|c|c|c|}
\hline \multirow{2}{*}{ S No } & \multirow{2}{*}{ Code of bacterial isolates } & \multicolumn{4}{|c|}{ Lytic enzyme production } & \multirow{2}{*}{ HCN production } & \multirow{2}{*}{ Exopolysaccharide production } \\
\hline & & Amylase & Protease & Cellulase & Pectinase & & \\
\hline 1 & $2^{\text {nd }} f$ soil- 1 & - & +++ & - & - & - & ++ \\
\hline 2 & $2^{\text {nd }} f$ soil- 5 & - & +++ & +++ & - & +++ & ++ \\
\hline 3 & $2^{\text {nd }} f$ soil- 20 & - & +++ & - & - & - & + \\
\hline 4 & $2^{\text {nd }} f$ soil- 30 & - & +++ & + & + & + & +++ \\
\hline 5 & $2^{\text {nd }} f$ RW-8st & - & + & - & - & - & - \\
\hline 6 & $2^{\text {nd }} f$ RW-10 & ++ & ++ & - & - & +++ & - \\
\hline 7 & $2^{\text {nd }} f$ RW-11 & - & - & - & - & - & + \\
\hline 8 & $2^{\text {nd }} f \mathrm{RW}-15$ & - & +++ & + & - & + & ++ \\
\hline 9 & $2^{\text {nd }} f$ RW-27 & - & - & - & - & - & + \\
\hline 10 & $2^{\text {nd }} f$ RW-29 & - & +++ & - & - & - & - \\
\hline 11 & $2^{\text {nd }} f R W-38$ & +++ & +++ & - & - & - & + \\
\hline 12 & $2^{\text {nd }} f$ RW- $42^{\text {nd }}$ & +++ & +++ & - & - & +++ & + \\
\hline
\end{tabular}

Characterization of Bacterial Isolates for Abiotic Stress Factors

All bacterial isolates were characterized for abiotic stress factors tolerance activities such as $(5 \% \mathrm{NaCl}, 10 \% \mathrm{NaCl}, 15 \% \mathrm{NaCl}$ and $20 \% \mathrm{NaCl} \mathrm{w/v),} \mathrm{(4,} \mathrm{5,} \mathrm{7,} 11$ and $13 \mathrm{pH}$ ranges), and different temperature ranges i.e. $(4,20,30,40,50$ and $600 c)$. Among these $60.8 \%$ (278) bacterial isolates were survived at $5 \% \mathrm{NaCl} w / v, 15.5$ $\%$ (69) bacterial isolates were survived at $10 \% \mathrm{NaCl} w / \mathrm{v}, 2.2 \%$ (10) isolates were survived at $15 \% \mathrm{NaCl} \mathrm{w} / \mathrm{v}$ and $0.7 \%$ (3) isolates were survived at $20 \% \mathrm{NaCl} \mathrm{w} / \mathrm{v}$. For $\mathrm{pH}$ tolerance test, all bacterial isolates were survived at $\mathrm{pH}-7$ and there is no bacterial isolates were survived at $\mathrm{pH}-13,1.8 \%$ (8) bacterial isolates were survived at $\mathrm{pH}-4,25.5 \%$ (117) bacterial isolates were survived at $\mathrm{pH}-5$, $25 \%$ (114) bacterial isolates were survived at $\mathrm{pH}-9$ and $1.6 \%$ (7) bacterial isolates were survived at $\mathrm{pH}-11$. For temperature tolerance test, all bacterial isolates were survived at 20 and $30^{\circ} \mathrm{C}$ and there is no bacterial isolates survived at $60{ }^{\circ} \mathrm{C}, 20 \%$ (91) isolates were survived at $4{ }^{\circ} \mathrm{C}, 40.7 \%$ (186) were survived at 40 ${ }^{\circ} \mathrm{C}$, and $0.8 \%$ (4) bacterial isolates were survived at $50^{\circ} \mathrm{C}$ (Table 4). 
Table 4: Characterization of bacterial isolates for abiotic stress factors.

\begin{tabular}{|c|c|c|c|c|c|c|c|c|c|c|c|c|c|c|c|c|}
\hline \multirow{3}{*}{$\begin{array}{l}\text { Code of bacterial } \\
\text { isolates }\end{array}$} & \multicolumn{16}{|c|}{ Bacteria abiotic stress tolerance test } \\
\hline & \multicolumn{4}{|c|}{$\begin{array}{l}\text { Different conc. of } \% \mathrm{NaCl} \\
\qquad(w / v)\end{array}$} & \multicolumn{6}{|c|}{ Different $\mathrm{pH}$ ranges } & \multicolumn{6}{|c|}{ Different Temperature ranges ${ }^{\circ} \mathrm{c}$} \\
\hline & 5 & 10 & 15 & 20 & 4 & 5 & 7 & 9 & 11 & 13 & 4 & 20 & 30 & 40 & 50 & 60 \\
\hline $2^{\text {nd }} f$ soil -1 & $\sqrt{ }$ & $\sqrt{ }$ & $x$ & $x$ & $x$ & $\sqrt{ }$ & $\sqrt{ }$ & $\sqrt{ }$ & $\sqrt{ }$ & $x$ & $\sqrt{ }$ & $\sqrt{ }$ & $\sqrt{ }$ & $\sqrt{ }$ & $x$ & $x$ \\
\hline $2^{\text {nd }} f$ soil- 5 & $\sqrt{ }$ & $\sqrt{ }$ & $x$ & $x$ & $x$ & $\sqrt{ }$ & $\sqrt{ }$ & $\sqrt{ }$ & $\sqrt{ }$ & $x$ & $x$ & $\sqrt{ }$ & $\sqrt{ }$ & $x$ & $x$ & $x$ \\
\hline $2^{\text {nd }} f$ soil- 20 & $\sqrt{ }$ & $\sqrt{ }$ & $\sqrt{ }$ & $\sqrt{ }$ & $x$ & $\sqrt{ }$ & $\sqrt{ }$ & $x$ & $x$ & $x$ & $x$ & $\sqrt{ }$ & $\sqrt{ }$ & $\sqrt{ }$ & $x$ & $x$ \\
\hline $2^{\text {nd }} f$ soil- 30 & $\sqrt{ }$ & $\sqrt{ }$ & $\sqrt{ }$ & $x$ & $x$ & $\sqrt{ }$ & $\sqrt{ }$ & $x$ & $x$ & $x$ & $x$ & $\sqrt{ }$ & $\sqrt{ }$ & $\sqrt{ }$ & $x$ & $x$ \\
\hline $2^{\text {nd }} f$ RW-8st & $x$ & $x$ & $x$ & $x$ & $x$ & $\sqrt{ }$ & $\sqrt{ }$ & $x$ & $x$ & $x$ & $\sqrt{ }$ & $\sqrt{ }$ & $\sqrt{ }$ & $\sqrt{ }$ & $x$ & $x$ \\
\hline $2^{\text {nd }} f R W-10$ & $x$ & $x$ & $x$ & $x$ & $x$ & $x$ & $\sqrt{ }$ & $x$ & $x$ & $x$ & $x$ & $\sqrt{ }$ & $\sqrt{ }$ & $x$ & $x$ & $x$ \\
\hline $2^{\text {nd }} f \mathrm{RW}-11$ & $\sqrt{ }$ & $x$ & $x$ & $x$ & $\sqrt{ }$ & $\sqrt{ }$ & $\sqrt{ }$ & $\sqrt{ }$ & $x$ & $x$ & $\sqrt{ }$ & $\sqrt{ }$ & $\sqrt{ }$ & $\sqrt{ }$ & $x$ & $x$ \\
\hline $2^{\text {nd }} f$ RW-15 & $\sqrt{ }$ & $x$ & $x$ & $x$ & $\sqrt{ }$ & $\sqrt{ }$ & $\sqrt{ }$ & $\sqrt{ }$ & $x$ & $x$ & $\sqrt{ }$ & $\sqrt{ }$ & $\sqrt{ }$ & $\sqrt{ }$ & $x$ & $x$ \\
\hline $2^{\text {nd }} f R W-27$ & $\sqrt{ }$ & $\sqrt{ }$ & $\sqrt{ }$ & $x$ & $x$ & $\sqrt{ }$ & $\sqrt{ }$ & $\sqrt{ }$ & $x$ & $x$ & $x$ & $\sqrt{ }$ & $\sqrt{ }$ & $\sqrt{ }$ & $x$ & $x$ \\
\hline $2^{\text {nd }} f R W-29$ & $\sqrt{ }$ & $\sqrt{ }$ & $x$ & $\times$ & $\sqrt{ }$ & $\sqrt{ }$ & $\sqrt{ }$ & $x$ & $x$ & $x$ & $\sqrt{ }$ & $\sqrt{ }$ & $\sqrt{ }$ & $\sqrt{ }$ & $\sqrt{ }$ & $x$ \\
\hline $2^{\text {nd }} f R W-38$ & $\sqrt{ }$ & $x$ & $x$ & $x$ & $x$ & $\sqrt{ }$ & $\sqrt{ }$ & $x$ & $x$ & $x$ & $x$ & $\sqrt{ }$ & $\sqrt{ }$ & $\sqrt{ }$ & $x$ & $x$ \\
\hline $2^{\text {nd }} f R W-42^{\text {nd }}$ & $\sqrt{ }$ & $\sqrt{ }$ & $x$ & $x$ & $x$ & $\sqrt{ }$ & $\sqrt{ }$ & $x$ & $x$ & $x$ & $\sqrt{ }$ & $\sqrt{ }$ & $\sqrt{ }$ & $\sqrt{ }$ & $x$ & $x$ \\
\hline
\end{tabular}

Note: $x=$ No survived, $\sqrt{ }=$ survived

\section{Biolog Bacterial Biochemical Characterization and Identification}

12 tef rhizosphere colonizing bacterial species and strains having different plant growth-promoting traits, biocontrol properties, and abiotic stress factors tolerance ability were characterized for different Biolog carbon source utilization and oxidation test. Biolog carbon sources were divided into six categories such as polymers (dextrin, $\beta$-cyclodextrin), carbohydrates ( $\alpha$-D-glucose, D-sorbitol, D-fructose, maltose, sucrose, arbutin, gentiobiose, and 3-methyl-glucose), carboxylic acids (pyruvic acid, lactic acid, acetic acid, citric acid, methyl pyruvate and mono-methyl-succinate), amide and amine (succinamic acid, L-alaninamide and putrescine), amino acids (D-alanine, L-alanine, L-asparagine and L-glutamic acid and L-serine), and miscellaneous (salicin, glycerol, 2,3-butanediol, 2 '-deoxyadenosine, inosine, tween 80 and uridine). Among these $100 \%$ (12) rhizobacterial species were utilized acetic acid, 75\% (9) species were utilized L-Glutamic acid, L-lactic acid, citric acid, L-malic acid, L-Serine, and L-Histidine. $66.7 \%$ (8) species were utilized as propionic acid and L-alanine. 58.3\% (7) species were utilized L-arginine, L-aspartic acid, methyl pyruvate, and glycerol. $41.7 \%$ (5) species were utilized $\alpha$-D-glucose, D-fructose, and D-glucoronamide. 33.3\% (4) species were utilized D-maltose, D-mannose, D-trehalose, and N-acetyl- D-glucosamine (Table 5 \& Figure 2).

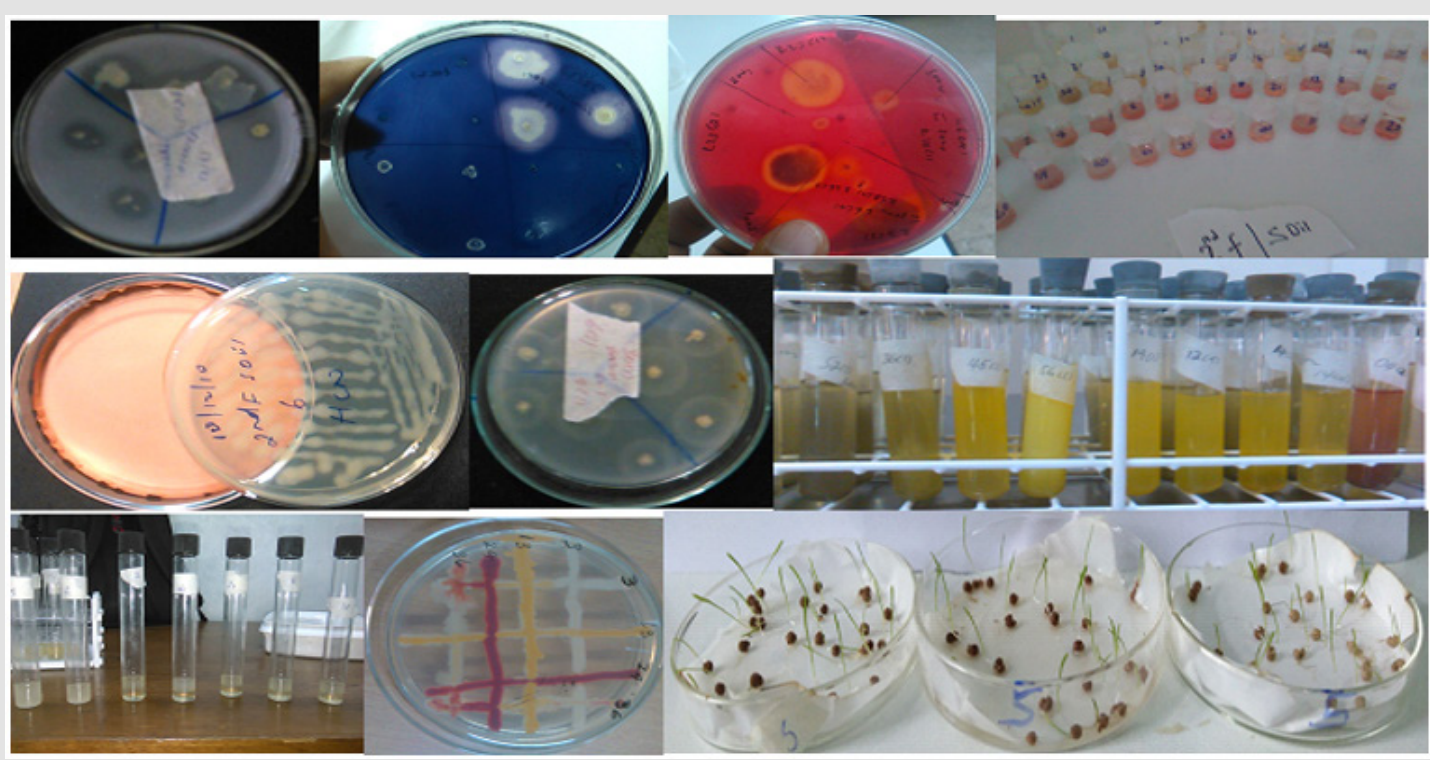

Figure 2: (a) phosphate solubilization (b) amylase production (c) cellulase (d) IAA production (e) HCN production (f) protease production $(\mathrm{g}) \mathrm{NH}_{3}$ production $(\mathrm{h})$ EPS production $(\mathrm{g})$ bacterial compatibility test and $(\mathrm{j})$ seed germination. 
Table 5: Biolog bacterial biochemical characterization and identification.

\begin{tabular}{|c|c|c|c|c|c|c|c|c|c|c|c|c|}
\hline \multirow{2}{*}{ 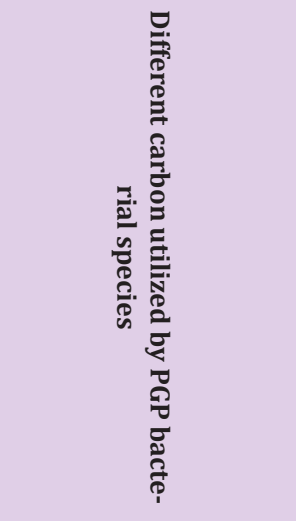 } & \multicolumn{12}{|c|}{ Identified PGP bacterial species or strains } \\
\hline & 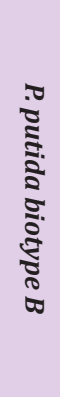 & 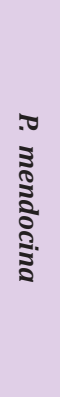 & 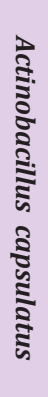 & 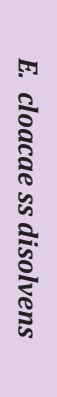 & 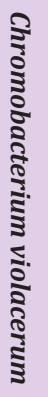 & 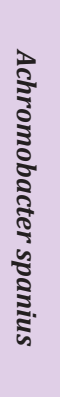 & $\stackrel{\rho}{\Omega}$ & 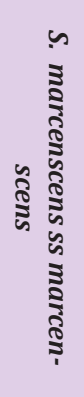 & 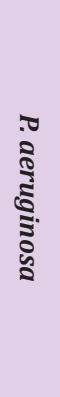 & 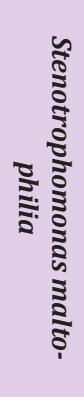 & 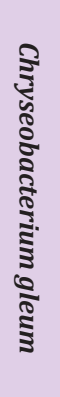 & 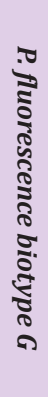 \\
\hline D-Maltose & - & - & - & + & - & - & - & + & - & + & + & - \\
\hline D-Trehalose & - & - & - & + & - & - & - & + & - & + & + & - \\
\hline N-Acetyl-d-glucosamine & - & - & - & + & + & - & - & + & - & + & - & - \\
\hline$\alpha$-D-glucose & - & - & - & + & + & - & - & - & + & + & - & + \\
\hline D-Mannose & - & - & - & + & - & - & - & + & - & + & + & - \\
\hline D-Fructose & - & - & - & + & - & - & - & + & + & - & + & + \\
\hline Glycerol & - & + & - & + & + & - & + & + & + & - & + & - \\
\hline L-Alanine & - & + & + & + & + & - & + & + & + & + & - & - \\
\hline L-Arginine & + & + & + & - & + & - & - & - & + & - & + & + \\
\hline L-Aspartic acid & - & + & + & + & + & - & + & + & + & - & + & - \\
\hline L-Glutamic acid & + & + & + & + & + & + & - & + & + & - & + & - \\
\hline L-Histidine & + & + & + & + & + & + & - & + & + & - & - & + \\
\hline L-Serine & + & + & + & + & + & - & + & + & + & + & - & - \\
\hline D-Glucuronamide & + & + & + & - & - & + & + & - & - & - & - & - \\
\hline Methyl pyruvate & - & - & + & + & + & - & - & + & + & + & - & + \\
\hline L-Lactic acid & - & + & + & + & + & + & - & + & + & + & - & + \\
\hline Citric acid & + & + & + & + & - & + & - & + & + & + & - & + \\
\hline L-malic acid & + & + & + & - & + & - & + & + & + & + & - & + \\
\hline Propionic acid & + & + & + & - & + & - & - & + & + & + & - & + \\
\hline Acetic acid & + & + & + & + & + & + & + & + & + & + & + & + \\
\hline Probability (\%) & 69 & 62 & 58 & 92 & 0 & 55 & 98 & 73 & 59 & 67 & 53 & 38 \\
\hline
\end{tabular}

Note: - = No utilize carbon, $+=$ Utilize carbon

\section{Seed Germination and Seedling Growth Test}

Seed germination and seedling growth test was performed using 4 bacterial species (pseudomonas fluorescence biotype G, Enterobacter cloacae ss disolvens, Serretia marcescens ss marcescens and Chryseobacterium gleum) having excellent plant growth promoting, biotic and abiotic stress tolerance properties. Seed coating was made by using single and consortium bacterial inoculation system. Seed germination rate and growth status was calculated. Shoot and root length was measured to determine effect of single and co-inoculation of identified bacterial species as follows; five seedlings were randomly selected from each Petri dish and measured with a measuring tape and expressed in centimeters. Measurement was taken after 7 days of seed setting. Those selected potential PGP bacterial species were inoculated in to healthy tef seeds. Among these $100 \%$ seed germination result were occurred in all selected PGP bacterial species or strains such as on 3rd and on $4^{\text {th }}$ day after inoculation and also increase mean shoots and roots length up to 3 and $2.6 \mathrm{~cm}$ respectively in comparison to control. Vigor index of seedling were measured from380 up to 550

\section{Discussion}

Plant growth-promoting bacteria are beneficial soil bacteria that competing rhizosphere and stimulating plant growth and yield by various mechanisms. The use of native PGP bacteria as bio inoculants in agricultural sectors to improve crop yield, grain quality and maintaining soil fertility is suitable to sustain crop production and productivity. PGPR directly affect plant growth by improving nutrient assimilation through fixation of atmospheric nitrogen, solubilization of insoluble phosphorus, siderophores production and/or other unavailable forms of nutrients and indirectly promote plant growth through the production of lytic enzymes, antibiotics, and secondary metabolites. 
In this study, 71 composite soil samples were analyzed for soil physicochemical properties such as soil texture, $\mathrm{pH}$, electric conductivity, available phosphate, organic matter, organic carbon and total nitrogen. The majority of experimental soils used in this study were found to be in the lower range of available phosphate at the alkaline soil pH. Soil pH has a great influence on soil chemical processes that determine the behavior of nutrients. Hence, it is also an important influencing factor for nutrient availability and plant growth. At alkaline $\mathrm{pH}$ values ( $>\mathrm{pH} 7.3$ ), phosphate ions tend to react quickly with calcium (Ca) and magnesium (Mg) to form less soluble compounds. A deficiency of phosphate in many agricultural soils is one of the major factors hampering crop production worldwide. phosphate solubilizing PGP bacteria that producing various organic acid, mineral acid and enzymes offer an alternative, eco-friendly strategy for enhancing the available phosphate concentration in the rhizosphere soil, while the use of chemicals can be reduced.

Bacterial phosphate solubilization ability is an important criterion for the selection of potential PGPR used as bio inoculant for improving plant growth and yield at the alkaline soil without harming living organisms and their environment. In this study, $71.3 \%$ of bacterial isolates were solubilizing insoluble phosphate. All the biochemically identified rhizobacterial species i.e. P. putida biotype B, P. mendocina, Actinobacillus capsulatus, Enterobacter cloacae ss disolvens, Chromobacterium violacerum, Achromobacter spanius, Escherichia coli, Serratia. marcescens ss marcescens, P. aeruginosa, Stenotrophomonas maltophilia, Chryseobacterium gleum and P. fluorescence biotype $G$ were solubilized insoluble phosphate at a rats 2 to 4 solubilization index and which have a great role in increasing crops productivity and production without contaminating the environment and living things. Bhattacharyya and Jha [35] have reported Azotobacter, Bacillus, Beijerinckia, Burkholderia, Enterobacter, Erwinia, Flavobacterium, Microbacterium, Pseudomonas, Rhizobium and Serratia as the most significant phosphate solubilizing bacteria.

Most of the soil bacteria including actinobacteria solubilize inorganic phosphate by secreting low molecular weight organic acids whereas mineralization of organic phosphorus occurs through the synthesis of a variety of different phosphatases [36]. Phosphate solubilizing activity is related to the microbial production of organic acids, which chelate the cation bound to phosphate, thereby converting it to a soluble form. In this study, $52 \%$ rhizobacteria isolates were colonizing tef rhizosphere during flowering stage were positive for organic acid production and enhance crop yield and grain quality. The results were supported by Bharucha et al. [38] who reported that PGPR isolated from Alfa Alfa rhizosphere soils produce organic acids and enhance plant growth. Different organic acids, such as glycolic acid, oxalic acid, malonic acid, succinic acid, citric acid, and propionic acid, have also been identified among phosphate solubilizers. Alternative possibilities other than organic acids include the release of $\mathrm{H}+$ to the outer surface in exchange for cation uptake or ATPase which can constitute alternative ways, with the help of $\mathrm{H}+$ translocation, for solubilization of mineral phosphates [37].

Soil pH can also play a role in Nitrogen volatilization losses. Ammonium in the soil solution exists in equilibrium with ammonia gas (NH3). The equilibrium is strongly pH-dependent. If $\mathrm{NH} 4+$ were applied to the soil at $\mathrm{pH}$ seven, the equilibrium condition would be $99 \%$ NH4+ and 1\% NH3. At pH 8, approximately $10 \%$ would exist as NH3 gas. This means that a fertilizer like urea is generally subject to slightly higher volatilization losses at a higher soil $\mathrm{pH}$. Use of nitrogen-fixing plant growth-promoting rhizobacterial inoculant as biofertilizers is one of the best alternative comparing to the chemical treatment for improving plant growth and its productivity through the production of complex nitrogenous enzymes. Nitrogen fixation ability is an important criterion for the selection of potential PGPR.

In this study, $10 \%$ of bacterial isolates were grown on $\mathrm{N}$-free agar media confirmed their potential of fixing atmospheric nitrogen on such media. Our result was supported by the findings of Naher et al. [39] who characterized a few N-fixing bacteria by acetylene reduction assay (ARA). The growth promotion effects of diazotrophic PGPR strains on rice have been reported by Ashraf et al. [40]. In this way, PGPR provides an attractive alternative for the chemical source of nitrogen fertilization. IAA is one of the most important phytohormones which may function as an important signal molecule in the regulation of plant growth. In the present study out of 457 bacterial isolates colonizing tef rhizosphere, 57.1 $\%$ bacterial were produced IAA. Rhizobacterial species identified from the rhizosphere are more efficient IAA producers than isolates from the non-rhizosphere soil. This is an important mechanism of plant growth promotion because IAA promotes root development and uptake of nutrients [41].

It has long been proposed that IAA act coordinate demand and acquisition of nitrogen and enhance crop yields. In this regard, Patten and Glick showed that the production of IAA by Pseudomonas putida was closely linked to the optimal development of the root system in Brassica napus L. and Vigna radiata [42]. Another important trait of PGPR in the production of ammonia that indirectly influences plant growth. In this study, $12 \%$ of the isolates were able to produce ammonia, which is an inorganic volatile, may be useful in biocontrol as demonstrated by Howell et al. [43] where ammonia, produced by PGP bacterial species, appeared to be one of the many mechanisms that bacteria use in the biocontrol of preemergence damping-off caused by fungal pathogens. The presence of ammonia producing PGP bacteria is indicative for PGP bacterial biocontrol properties were takes place in the rhizosphere than nonrhizosphere soil. Hydrolytic enzymes act as agents for prevention of plant diseases by causing lysis of pathogenic microbes in the close vicinity of the plant as they secrete increased level of cell wall lytic enzymes (chitinase, glucanase, lipase, and proteases) [44]. In this study, $65.4 \%$ isolates were positive for protease production, 20.6 $\%$ isolates were positive for amylase production, $8 \%$ isolates were positive for cellulase production, and $0.3 \%$ isolates were positive 
for pectinase production. PGPR that synthesizes one or more of these lytic enzymes has been found to have the ability to control a range of plant pathogenic fungi and bacteria and enhance crop productivity. Bull et al. [45] who reported that Lysobacter and Myxobacteria produces lytic enzymes have shown effectiveness against some plant pathogenic fungi.

HCN production by rhizobacteria has been postulated to play an important role in the biological control of pathogens [46]. In this study, $15.4 \%$ of the bacterial isolates were positive for HCN production, which acts as an inducer of plant resistance. Several factors have been reported to influence the rate of HCN production. Glycine is the direct precursor of microbial cyanide production and it has been found in root exudates [47]. HCN secreted by P. fluorescent strain has been demonstrated to stimulate root hair formation and suppress back root rot caused by Thielaviopsis basicola in tobacco plant [48]. Exopolysaccharide is the active constituents of soil organic matter. The important functions showed by exopolysaccharide extracted from PGP bacteria are (1) Protective, (2) surface attachment, (3) biofilm formation, (4) microbial aggregation, (5) plant-microbe interaction, and (6) bioremediation [49]. In this study, $18.6 \%$ of bacterial isolates were producing EPS. EPS-producing PGPR can significantly enhance the volume of soil macropores and the rhizosphere soil aggregation, resulting in increased water and fertilizer availability to the applied plants [50].

Exopolysaccharide protects beneficial rhizosphere competing bacteria from various environmental stresses [51], protects cells from antimicrobial compounds, and antibodies, or for sticking to other bacteria, animal and plant tissues. Abiotic stresses are major factors that limit crop production and are the cause of more than $30 \%$ of worldwide losses [52]. Abiotic stress factors include temperature, $\mathrm{pH}$, salinity and heavy metal contamination. Importantly, even though many plant growth-promoting bacteria associated with plant rhizosphere show good results during in vitro evaluation and they fail in the field when applied as plant growthpromoting abiotic stress tolerating bacterial inoculants. One main reason for their failure is the stress imposed on them by the sudden change of soil physical, chemical and biological matters in the environment [53].

Characterization of PGP bacteria for stress tolerance ability is an important factor in the selection of potential bacterial species for the development of PGP bacterial inoculants to sustain agricultural production and productivity. Salinity is one of the most important abiotic stress factors that undesirably affect plant growth and productivity in the world. It is one of the global problems that affect agricultural productivity and production: about $20 \%$ of cultivated lands and $50 \%$ of irrigated areas are affected by salinity. Plants growing in saline soil frequently increase their ethylene production in order to initiate programmed cell death (apoptosis). Our results showed that $60.8 \%$ isolates were survived at 5\% salinity, $15.5 \%$ isolates were survived at $10 \%$ salinity, $10 \%$ isolates were survived at $15 \%$ salinity and $0.7 \%$ isolates were survived at $20 \%$ salinity and thus are showed that their ability to survive in a saline environment. Soil salinity has been reported to limit plants productivity and production through affecting plants photosynthetic ability, protein synthesis, energy and lipid metabolism, and the total nitrogen contents [54]. pH is another abiotic stress factors that limit PGP bacterial properties in the rhizosphere. In the present study, all PGP bacterial colonies isolated from tef rhizosphere were survived at $\mathrm{pH}-7,25.5 \%$ isolates were survived at $\mathrm{pH}-5,1.8 \%$ of the isolates were survived at $\mathrm{pH}-4,25 \%$ of the isolates were at $\mathrm{pH}-9$ and $1.6 \%$ of the isolates were survived at $\mathrm{pH}-11$. This indicates that thus tef rhizosphere competing PGP bacterial isolates can tolerate a wide range of $\mathrm{p}^{\mathrm{H}}$ and confirmed their potential to survive in a wide range of $\mathrm{p}^{\mathrm{H}}$ in the rhizosphere. Temperature also another abiotic stress factor that limits PGPR properties in the rhizosphere, in this study all PGP bacterial isolates isolated from tef rhizosphere were survived at 20 and $30{ }^{\circ} \mathrm{C}, 20 \%$ of were survived at $4{ }^{\circ} \mathrm{C}, 40.7$ $\%$ isolates were survived at $40{ }^{\circ} \mathrm{C}$, and $0.8 \%$ of the isolates were survived at $50{ }^{\circ} \mathrm{C}$.

This result showed that isolates were survived at wide range temperatures and improve plant growth and yield.

PGP rhizobacterial species or strains can produce the enzyme 1-aminocyclopropane-1-carboxylic acid (ACC) deaminase that breaks down ACC, the direct precursor of ethylene, into ammonia and a-ketobutyrate and support the plants for vigorous growth and development at environmental conditions. For seed germination and seedling growth status evaluation, a seed of tef was inoculated with 4 identified PGP bacterial species having excellent PGP traits. Seed coating was made by using single and consortium bacterial inoculation system. All of the tef seeds inoculated with potential PGP bacterial species or strains were germinate tef seeds up $100 \%$ on 3rd and 4th days after inoculation and increase mean shoot length and roots length of the inoculated seeds up to 3 and $2.6 \mathrm{~cm}$ respectively in comparison to control (Table 6).

Table 6: Seeds germination and seedling growth rate..

\begin{tabular}{|c|c|c|c|c|c|c|c|}
\hline \multicolumn{5}{|c|}{ Number of Germinated Seeds/Days } & \multirow{2}{*}{ Mean Shoot Length (cm) } & \multirow{2}{*}{ Mean Root Length (cm) } & \multirow{2}{*}{ Seed Vigor Index } \\
\hline Code & $2^{\text {nd }}$ day & $3^{\text {rd }}$ day & $4^{\text {th }}$ day & $\%$ Seed germination & & & \\
\hline $2^{\text {nd }} f$ soil 20 & 10 & 23 & 25 & 100 & 2.5 & 1.3 & 380 \\
\hline $2^{\text {nd }} f$ soil 30 & 11 & 25 & 25 & 100 & 3 & 2.4 & 540 \\
\hline $2^{\text {nd }} f$ RW 15 & 12 & 25 & 25 & 100 & 2.7 & 2.6 & 530 \\
\hline $2^{\text {nd }} f$ RW 38 & 13 & 25 & 25 & 100 & 2.8 & 1.2 & 400 \\
\hline Consortium & 13 & 25 & 25 & 100 & 3 & 2.5 & 550 \\
\hline
\end{tabular}


Vigor index of seedling was measured from380 to 550 on the last day of the experiment. Pradhan [55], he reported that seeds inoculated with Bacillus sp. were significantly increased the germination percentage, root and shoot length of the crops as compared to the untreated one. Besides, Pieterse and Van Loon [56] reported that $30 \%$ growth improvement of Arabidopsis accession was grown in autoclaved soil due to inoculation with Pseudomonas fluorescens. According Woyessa and Assefa [57] report inoculation of tef crops with Pseudomonas fluorescent identified from tef rhizosphere increases mean root dry weight up to $39 \%$, root shoot ratio up to $42 \%$, and grain yield up to $28 \%$ and also tef crops inoculated with Bacillus subtilis that increase mean root dry weight of tef up to $28 \%$, root shoot ratio up to $19 \%$ and grain yield up to $44 \%$.

\section{Conclusion and Recommendation}

At a global scale, the effects of continuous and heavy use of agrochemicals for improving agricultural productivity and production can cause serious damage on the soil fertility, a life of living organisms and as well as their environment. Use of plant growth-promoting rhizobacteria species or strains as agricultural crop inoculums is costly reasonable and environmentally-friendly approach to increase crop production on a sustainable way. The plant-beneficial PGP rhizobacterial bio inoculum may decrease the global dependence on hazardous agrochemicals which threaten the ecosystems. PGPR protect the plants from the deleterious effects of pathogenic microorganisms and abiotic stresses problems through solubilizing insoluble phosphate, secreting organic acid, phytase, phosphatase enzymes, producing phytohormones, antioxidant enzymes. Rhizobacteria can produce ACC-deaminase and fixe atmospheric nitrogen is more effective than rhizobacteria that can produce either ACC-deaminase or nitrogen-fixing activity alone for growth promotion of crops. The results are promising for the design of potentially active PGP bacterial based bio inoculums formulation which would be very important for improving crop growth and yield. These identified potential plant growth-promoting species or strains associated with tef rhizosphere during the flowering stage can be used as bio inoculants for maintaining sustainable agricultural production and productivity without affecting soil fertility, a life of living organisms and also their environment.

\section{Acknowledgment}

First, I would like to thank ministry of innovation and technology, AAU for financial support, Ethiopian biodiversity institute, and DZARC for materials and technical support.

\section{References}

1. Hiltner L (1904) Ueber neuere Erfahrungen und Probleme auf dem Gebiete der Bodenbakteriologie und unter besonderer BerUcksichtigung der Grundungung und Brache. Arb Deut Landw Gesell 98: 59-78.

2. Tsegaye Z, Assefa F, Beyene D (2017) Properties and Application of Plant Growth Promoting Rhizobacteria. I J Curr Trend Pharmacobiol Med Sci 2(1): 30-43.

3. Muleta D, Assefa F, Granhall U (2007) In vitroantagonism of rhizobacteria isolated from Coffea arabicaL. against emerging fungal coffee pathogens. Eng Life Sci 7: 1-11.
4. Liu L, Kloepper JW, Tuzun S (1995) Induction of systemic resistance in cucumber against bacterial angualar leaf spot by plant growthpromoting rhizobacteria. Phytopathol 85(6): 843-847.

5. Kloepper JW (1994) Plant growth-promoting rhizobacteria (other systems). In: Azospirillum/Plant Associations (Ed. Okon Y). CRC Press, Boca Raton, FL, USA, pp. 111-118.

6. Vacheron J, Desbrosses G, Bouffaud ML, Touraine B, Moënne Loccoz Y, et al. (2013) Plant growth-promoting rhizobacteria and root system functioning. Front. Plant Sci 4: 356.

7. Ajar NY, Priyanka V, Bhanumati S, Vinay SC, Archna S, et al. (2017) Plant Growth Promoting Bacteria: Biodiversity and Multifunctional Attributes for Sustainable Agriculture. Adv Biotech \& Micro 5(5): 555671.

8. Baset Mia MA, Shamsuddin ZH, Wahab Z, Marziah M (2010) Effect of plant growth-promoting rhizobacterial (PGPR) inoculation on growth and nitrogen incorporation of tissue-cultured Musa plantlets under nitrogen-free hydroponics condition. AJCS 4(2): 85-90.

9. Jacobson CB, Pasternak JJ, Glick BR (1994) Partial purification and characterization of ACC deaminase from the plant growth-promoting rhizobacterium Pseudomonas putida GR12-2. Can J Microbiol 40: 10191025.

10. Glick BR, Penrose DM, Li J (1998) A model for the lowering of plant ethylene concentrations by plant growth-promoting bacteria. J Theor Biol 190(1): 63-68.

11. Vivekananthan R, Ravi M, Ramanathan A, Samiyappan R (2004) Lytic enzymes induced by Pseudomonas fluorescens and other biocontrol organisms mediate defense against the anthracnose pathogen in mango. World J Microbiol Biotechnol 20(3): 235-244.

12. McCully ME (2001) Niches for bacterial endophytes in crop plants: a plant biologist's view. Aust J Plant Physiol 28(9): 983-990.

13. Benizri E, Baudoin E, Guckert A (2001) Root colonization by inoculated plant growth-promoting rhizobacteria. Biocontrol Sci Technol 11: 557574.

14. Gamalero E, Lingua G, Berta G, Glick BR (2009) Beneficial role of plant growth-promoting bacteria and arbuscular mycorrhizal fungi on plant responses to heavy metal stress. Can J Microbiol 55: 512-514.

15. Company S, Clément C, Sessitsch A (2010) Plant growth-promoting bacteria in the rhizo- and endosphere of plants: Their role, colonization, mechanisms involved and prospects for utilization. Soil Biol. Biochem 42(5): 669-678.

16. Vessey JK (2003) Plant growth-promoting rhizobacteria as biofertilizers. Plant-soil 255(2): 571-586.

17. Tsegaye Z, Gizaw B, Tefera G, Feleke A, Chaniyalew S, et al. (2019) Isolation and biochemical characterization of Plant Growth Promoting (PGP) bacteria colonizing the rhizosphere of Tef crop during the seedling stage. J Plant Sci Phytopathol 3: 013-027.

18. Gemechu D (1977) Aspects of climate and water budget in Ethiopia. Addis Ababa University Press p. 77.

19. Olsen SR, Sommers LE (1982) Phosphorus. In: AL page et al. (Eds.), Methods of soil analysis, ( $2^{\text {nd }} e d n$.). Agronomy 9: 403-430.

20. Keeney DR, Nelson DW (1982) Nitrogen-Inorganic Forms. In: AL Page (Ed.), Methods of Soil Analysis, Agronomy Monograph 9: Part 2 (2 ${ }^{\text {nd }}$ edn.), pp. 643-698.

21. Ngamau CN, Matiru VN, Tani A, Muthuri CW (2012) Isolation and identification of endophytic bacteria of bananas (Musa spp.) in Kenya and their potential as biofertilizers for sustainable banana production. Afr J Microbiol Res 6(34): 6414-6422.

22. Pikovskaya RE (1948) Mobilization of phosphorus in soil in concentration with vital activity of some microbial species. Microbiology 17: 362 .

23. Trivedi MK, Patil S, Tallapragada RM (2003) Effect of biofield treatment on the physical and thermal characteristics of vanadium pentoxide powders. J Mater Sci Eng 11: 001. 
24. Brick JM, Bostock RM, Silverstone SE (2004) Rapid in situ assay for indole acetic acid production by bacteria immobilized on the nitrocellulose membrane. Appl Environ Microbial 57(2): 535-538.

25. Kumar A, Kumar A, Devi S, Patil S, Paya C, Negi S (2012) Isolation, screening and characterization of bacteria from rhizospheric soils for different Plant Growth Promotion (PGP) activities. An In vitro study Rec Res Sci Techno 4(1): 01-05.

26. Castric PA (1975) Hydrogen cyanide, a secondary metabolite of Pseudomonas aeruginosa. Can J Microbiol 21(5): 613-618.

27. Chang WT, Hsieh CH, Hsieh HS, Chen C (2009) Conversion of crude chitosan to an anti-fungal protease by Bacillus cereus. World Journal of Microbiology and Biotechnology 25(3): 375-382.

28. Khianngam S, Pootaeng-on Y, Techakriengkrai T, Tanasupawat S (2014) Screening and identification of cellulase-producing bacteria isolated from oil palm meal. J App Pharm Sci 4 (4): 090-096.

29. Andro T, Chambost JP, Kotoujansky A, Cattaneo J, Bertheau Y, et al. (1984) Mutants of Erwinia chrysanthemi defective in the secretion of pectinase and cellulase. J Bacteriol 160(3): 1199-1203.

30. Punitha A, Basil Rose MR, Albino Wins J, Prakash Shoba S, Mary Mettilda Bai S (2012) Studies on amylase activity of an amylolytic bacterium isolated from estuarine soil. African Journal of Biotechnology 11(42): 10015-10020.

31. Soares MMCN, Da Silva R, Gomes E (1990) Screening of bacterial strains for pectinolytic activity: characterization of the polygalacturonase produced by Bacillus sp. Rev Microbial 30(4): 299-303.

32. Santi LP, Ai Dariah, dan Goenadi DH (2008) The increase in mineral soil aggregate stability by exopolysaccharide-producing bacteria (In Bahasa Indonesia). Journal Menara Perkebunan 76(2): 93-103.

33. Abdul Baki AA, Anderson JD (1973) Vigor determination in soybean seed by multiple criteria. Crop Sci 13: 630-633.

34. Blume HP, Brümmer GW, Fleige H, Horn R, Kandeler E, et al. (2016) Scheffer/Schachtschabel Soil Science Heidelberg: Springer.

35. Naher UAO, Radziah ZH, Shamsuddin MS, Halimi, M Razi I (2009) Isolation of diazotrophs from different soils of Tanjong Karang ricegrowing area in Malaysia. Int. J Agric Biol 11(5): 547-552.

36. Bhattacharyya P, Jha D (2012) Plant growth-promoting rhizobacteria (PGPR): emergence in agriculture. World Journal of Microbiology and Biotechnology 28(4): 1327-1350.

37. Rodríguez H, Fraga R (1999) Phosphate solubilizing bacteria and their role in plant growth promotion. Biotechnol Adv 17(4-5): 319-359.

38. Habib SH, Kausar H, Saud HM, Ismail MR, Othman R (2016) Molecular Characterization of Stress Tolerant Plant Growth Promoting Rhizobacteria (PGPR) for Growth Enhancement of Rice. Int J Agric Biol 18 (1): 1560-8530.

39. Bharucha UD, Patel KC, Trivedi, UB (2013) In vitro screening of isolates for its plant growth-promoting activities from the rhizosphere of Alfalfa (Medicago Sativa)'. J Microbiol Biotech Res 3: 79-88.

40. Ashraf A M, Asif M, Zaheer A, Malik A, Ali Q, et al. (2013) Plant growthpromoting rhizobacteria and sustainable agriculture. African Journal of Microbiology Research 7(9): 704-709.
41. Patten CL, Glick BR (1996) Bacterial biosynthesis of indole-3 acetic acid. Canadian Journal of microbiology 42: 207-220.

42. Patten CL, Glick BR (2002) Role of Pseudomonas putida indole acetic acid in development of the host plant root system. Applied Environ Microbiol 68(8): 3795-3801.

43. Howell CR, Beier RC, Stipanovic RD (1988) Production of ammonia by Enterobacter cloacae and its possible role in the biological control of Pythium pre-emergence damping-off by the bacterium. Phytopathology 78: $1075-1078$

44. Carrillo AE, Li CY, Bashan Y (2002) Increased acidification in the rhizosphere of cactus seedlings induced by Azospirillum brasilense. Naturwissenschaften 89(9): 428-432.

45. Voisard C, Keel C, Hass D, Defago G (1989) Cyanide production by Pseudomonas fluorescens helps suppress black root rot of tobacco under gnotobiotic conditions. TheEMBO Journal 8(2): 351-358.

46. Devi R, Thakur R (2018) Screening and identification of bacteria for plant growth-promoting traits from termite mound soil. Journal of Pharmacognosy and Phytochemistry 7(2): 1681-1686.

47. Naseem H, Bano A (2004) Role of plant growth-promoting rhizobacteria and their exopolysaccharide in drought tolerance of maize. Journal of Plant Interactions 9(1): 689-701.

48. Upadhyay SK, Singh JS, Singh DP (2011) Exopolysaccharide-producing plant growth-promoting rhizobacteria under salinity condition. Pedosphere 21(2): 214-222.

49. Iqbal A, Bhatti HN, Nosheen S, Jamil A, Malik MA (2002) Histochemical and physicochemical Study of Bacterial Exopolysaccharides. Biotechnol 1(1): 28-33.

50. Das P, Behera BK, Meena DK, Azmi SA, Chatterjee S, et al. (2015) Salt stress tolerant genes in halophilic and halotolerant bacteria: Paradigm for salt stress adaptation an osmoprotectant. International Journal of Current Microbiology and Applied Sciences 4(1): 642-658.

51. Praveen Kumar G, Mir Hassan Ahmed SK, Desai S, Leo Daniel Amalraj E, Rasul A (2014) In vitro screening for abiotic stress tolerance in potent biocontrol and plant growth-promoting strains of Pseudomonas and Bacillus spp. International Journal of Bacteriology 6 .

52. Parida SK, Das AB (2005) Salt tolerance and salinity effects on plants. Ecotoxicol. Environ. Safety 60(3): 324-349.

53. Peleg Z, Apse MP, Blumwald E (2011) Engineering salinity and waterstress tolerance in crop plants: getting closer to the field. Adv Bot Res 57: 405-443.

54. Pradhan A, Mohapatra S, Mohanty D, Samantaray D, Mishra BB (2017) Effect of polyhydroxy alkanoates accumulated plant growth-promoting Bacillus sp. On germination and growth of Mung Bean and Groundnut. Res J Pharm Biol Chem Sci 8(4): 789-797.

55. Pieterse CMJ, Van Loon LC (1999) Salicylic acid-independent plant defense pathways. Trends Plant Sci 4(2): 52-58.

56. Woyessa D, Assefa F (2011) Effects of plant-growth-promotingrhizobacteria (PGPR) on growth and yield of Tef [Eragrostis tef (Zucc.)] under greenhouse condition. Res J Microbiol 6(4): 343-355. 
ISSN: 2574-1241

DOI: 10.26717/BJSTR.2019.22.003710

Zerihun Tsegaye. Biomed J Sci \& Tech Res

(C) (i) This work is licensed under Creative

Submission Link: https://biomedres.us/submit-manuscript.php

$\begin{array}{ll}\text { BIOMEDICAL } & \text { Assets of Publishing with us } \\ \text { RESEARCHES } & \text { - Global archiving of articles } \\ & \text { - Immediate, unrestricted online access } \\ & \text { - Rigorous Peer Review Process } \\ \end{array}$

